DOI: $10.14746 /$ por.2019.1.27

\title{
LITERACKIE ŚLADY LUDOBÓJSTWA
}

\author{
KATARZYNA TACZYŃSKA ${ }^{1}$
}

Morawiec, Arkadiusz. Literatura polska wobec ludobójstwa. Rekonesans. Łódź: Wydawnictwo Uniwersytetu Łódzkiego, 2018. 416 S.

Najnowsza monografia Literatura polska wobec ludobójstwa. Rekonesans Arkadiusza Morawca, wybitnego znawcy i badacza (nie tylko) polskiej literatury obozowej, to dzieło wyjątkowe, w którym autor pochyla się nad literaturą tematyzującą akty ludobójstwa i masowych zbrodni. Refleksja autora koncentruje się wokół dwudziestowiecznych praktyk ludobójczych, są to: przeprowadzona przez Turków eksterminacja Ormian, Holokaust, zagłada osób upośledzonych i psychicznie chorych, Porajmos, czyli zagłada Romów, oraz dokonana przez Serbów masakra w Srebrenicy. Badana przez Morawca literatura rozumiana jest zaś tutaj szeroko, omawiane są zarówno dzieła fikcjonalne, teksty paraliterackie, jak i dokumentarne, czyli literatura świadectwa. Podejmowana przez autora problematyka bez wątpienia wymaga rozległej wiedzy i erudycji, ogromnego doświadczenia badawczego i szczególnej wrażliwości, by przekonać krytyków i czytelników, że można, czy wręcz należy, i warto przyglądać się literaturze polskiej porównawczo, biorąc pod uwagę różne masowe zbrodnie. Na samym początku trzeba jednak zaznaczyć, by uchronić publikację przed zarzutami o relatywizm mordów - co zresztą czyni i sam autor - że tę specyficzną konfrontację trzeba tu rozumieć kontekstowo jako makabryczny, powtarzalny i powszechny w dziejach akt, który w różny sposób - od dominującego (Shoah) do marginalnego (zagłada Ormian) czy wręcz niemal nieobecnego (zagłada osób psychicznie chorych) w polskim dyskursie - pozostawił literacko utrwalone ślady. Odsłonięcie i uzasadnienie takiej perspektywy wymaga szczególnego wysił$\mathrm{ku}$. W literaturoznawstwie polskim nie podjęto jak dotąd próby rozpoznania tych zjawisk. Publikacja Morawca jest zatem studium o charakterze - jak zostało wyrażone w podtytule książki - rekonesansowym, w którym autor obserwacyjnie i eksplo-

1 E-mail: k.taczynska@wp.pl 
racyjnie pragnie wyznaczyć charakterystyczne dla literatury polskiej (tematyczne, formalne) granice związane z ludobójstwem.

Przypomnieć wypada, że dorobek badawczy w zakresie literatury obozowej profesora Morawca, związanego z Uniwersytetem Łódzkim, jest bogaty i rozległy. Pozostając tylko w kręgu książek autorskich, wymienić można monografie Zofia Romanowiczowa. Pisarka nie tylko emigracyjna (Łódź 2016), Literatura w lagrze, lager w literaturze. Fakt - temat - metafora (Łódź 2009), Seweryna Szmaglewska (1916-1992). Bibliografia (Łódź 2007), Poetyka opowiadań Gustawa Herlinga-Grudzińskiego. Autentyzm - dyskursywność - paraboliczność (Kraków 2000). Zważywszy jednak na profil i poetykę omawianej tutaj publikacji, warto zauważyć, że pomysł i potrzeba konfrontacji literatury ludobójstwa pojawiały się - co oczywiste - w działalności badacza już wcześniej, czego znaczący wyraz odnaleźć można przynajmniej w dwóch obszarach. Pierwszy z nich to zorganizowana w 2016 roku przez Katedrę Literatury Polskiej XX i XXI wieku Uniwersytetu Łódzkiego, w której na co dzień pracuje Morawiec, konferencja naukowa Lager, tagier i obóz - zapis. Przedmiotem zainteresowania badaczy i badaczek z różnych ośrodków w Polsce biorących w niej udział było - jak można przeczytać w zaproszeniu na to wydarzenie - zjawisko obozu, „obozu zagłady, obozu koncentracyjnego, obozu pracy niewolniczej, obozu represyjnego, obozu jenieckiego - oraz jego literackich reprezentacji, zapisów", zarówno w obszarze oddziaływania wpływów sowieckich (komunizmu), jak i niemieckich (nazistowskich), ale też innych. Kolejnym ważnym efektem oglądu problematyki obozowej w formule komparatystycznej są zredagowane przez Morawca dwa tematyczne tomy czasopisma "Acta Universitatis Lodziensis. Folia Litteraria Polonica", noszące tytuł Lager, łagier, obóz - zapis, przy czym nr 4 z 2017 roku nosi podtytuł Obszary, a nr 1 z 2018 roku - Lektury. Jak czytamy we wstępie drugiego z wymienionych numerów, chęć przygotowania obu tomów wypływała z poczucia pewnej stagnacji, wrażenia powtarzalności i tkwienia w utartych ramach i schematach interpretacyjnych, które mogą rodzić poczucie, że literatura obozowa w Polsce to temat opracowany. Tymczasem, jak przekonuje redaktor: „Nieprawdą jest, że polska literatura obozowa jest już dobrze rozpoznana. Prezentowane w tym oraz w poprzednim tomie artykuły dowodzą, że do uzyskania jej pełnego obrazu jest jeszcze daleko" (Morawiec 2018b: 6). Dodatkowym powodem mogła być - jak sądzę - świadomość braku platformy komunikacji pomiędzy reprezentantami badającymi problematykę obozową osadzoną w różnych kulturowych i społecznych kontekstach. Możliwość wymiany doświadczeń i obserwacji w trakcie konferencyjnych dyskusji, a w dalszej kolejności szczegółowa prezentacja problemu (wyzwań, dokonań, miejsc przemilczanych lub przy użyciu instrumentarium nowych dyskursów, na przykład ekokrytyki lub krytyki genderowej) w monograficznym tomie, była zatem dodatkowym atutem.

Literatura Holokaustu czy zbrodni komunistycznych jako punkt odniesienia dla innych (od niemieckich i sowieckich) narodowych zbrodni nie jest z pewno- 
ścią kwestią nową rozpatrywaną w badaniach obozowych. Przeciwnie, wydaje się, że odwoływanie się do kulturowego zaplecza opartego na osiągnięciach literatury dotyczącej Zagłady i łagrów jest w pewnym sensie krokiem oczywistym, do którego dochodzi zarówno we wspomnieniach ofiar, uczestników i świadków wydarzeń z przeszłości, jak i w opracowaniach badaczy tej literatury. Taką tekstową i doświadczeniową relację można zaobserwować na przykład w obszarze badań literatury obozowej w krajach byłej Jugosławii. Czytelnika wspomnień więźniarki obozu Goli otok (w publikacji podpisanej jako Novka) nie dziwi zapis, w którym autorka - była więźniarka obozu Auschwitz, ofiara eksperymentów in vivo (Simić, Trifunović 209), po wojnie w charakterze świadka zeznająca w procesie przeciwko Rudolfowi Hössowi - porównuje obóz w komunistycznej Jugosławii z obozami nazistowskimi (Jablanica, obóz w Niszu, Banjica w Belgradzie czy Auschwitz i Ravensbrück), przez które przeszła. Zdziwienie czy nawet niepokój u polskiego odbiorcy może wywołać natomiast jej stwierdzenie, iż obozy nazistowskie były rajem w stosunku do warunków obozu na wyspie (Simić, Trifunović 213). Przytoczony przykład nie jest przypadkiem odosobnionym, powraca we wspomnieniach więźniów i więźniarek obozów i więzień reedukacyjnych w Jugosławii. Przypomnijmy, Goli otok, czyli Naga Wyspa, to miejsce (dziś znajdujące się na terenie Chorwacji), w którym utworzono obóz reedukacyjny dla kominformowców, więźniów politycznych aresztowanych jako przeciwnicy polityki władzy jugosłowiańskiej po wykluczeniu kraju z Kominformu w 1948 roku. Większość więźniów opuściła wyspę na mocy amnestii po likwidacji Biura w 1956 roku i wówczas obóz został przekształcony w więzienie głównie o charakterze kryminalnym. Ostateczne zamknięcie więzienia na wyspie miało miejsce w 1988 roku. Do lat osiemdziesiątych obóz Goli otok zarówno w Jugosławii, jak i poza jej granicami funkcjonował jako temat tabu i dopiero po śmierci Tity w 1980 roku można mówić o faktycznym przełomie w dyskusji dotyczącej rozprawienia się z opozycją (por. Jezernik; Taczyńska). Z perspektywy historiograficznej dzisiejszy stan badań kazałby nam uznać, iż zastosowane przez Novkę porównanie jest pewnym nadużyciem. Jednak jego obecność rozpatrywana $\mathrm{w}$ kategoriach memory studies i pamięci jednostkowej znajduje zrozumienie. Tego typu porównanie przywoływane $\mathrm{w}$ świadectwach zapewne ściśle wiąże się z faktem wieloletniej marginalizacji w dyskursie publicznym problematyki obozowej, niemożnością wypowiedzenia przeżytych doświadczeń, podzielenia się przeszłością. Zagrożenie karą skutecznie wiązało usta byłym więźniom, którzy często nawet przed najbliższymi wiele lat ukrywali swoje wspomnienia². Ofiary - nierzadko skazane wyłącznie za pokrewieństwo z tzw. wrogiem ludu - były zmuszone do milczenia, a po odbyciu kary żyły ze stygmatem nieprzyjaciela i były poddawane ostracyzmowi społecznemu, miały utrudniony, a niejednokrotnie zamknięty dostęp na

2 Problem traumy międzypokoleniowej związanej z obozem Goli otok został w ciekawy sposób opracowany w filmie dokumentalnym Goli Tihej K. Gudac z 2014 roku. 
przykład do rynku pracy. Ważnym powodem blokującym głosy ofiar było ponadto poczucie winy wypływające $\mathrm{z}$ faktu, że w obozie więźniowie byli zmuszani do wzajemnego zadawania sobie kary, przez co niemal każdy z nich był obarczony w pewien sposób wyrzutami sumienia ${ }^{3}$. Ujmowanie różnych, odmiennych doświadczeń traumatycznych w ramy bliższe, bo powszechnie znane, jak perspektywa dramatu drugiej wojny światowej, jest zatem oczekiwanym i uprawnionym działaniem na początkowym etapie wyłaniania się tematu z publicznego niebytu, zanim wykształci się charakterystyczny dla danego obszaru paradygmat. Nie chodzi więc, jak w Literaturze polskiej wobec ludobójstwa... podkreśla Morawiec, opisując sytuację w literaturze polskiej, o „klasyfikowanie męki”, zabieg etycznie nieprzyzwoity (Morawiec 2018a: 6), lecz o dostrzeżenie pewnych wspólnych i pewnych zmiennych cech modelujących określony temat związany z ludobójstwem w dyskursie narodowym.

Przywołajmy jeszcze jeden przykład, ponownie zaczerpnięty z wydarzeń dotyczących tego samego fragmentu historii Jugosławii, w którym obóz na wyspie zestawiany jest z kulturowym i historycznym kontekstem Gułagu. Ta paralela wielokrotnie pojawia się w opracowaniach historyków i historyków literatury, a szczególnie wyraziście wybrzmiewa w recepcji dorobku Dragoslava Mihailovicia (ur. 1930), wybitnego serbskiego prozaika, który został aresztowany w wieku 19 lat i kolejno był przetrzymywany w więzieniach w Ćupriji, w Kragujevacu, w Belgradzie (Ada Ciganlija), a końcowo również w obozie Goli otok, do wiosny 1952 roku. Dragoslav Mihailović jest autorem pięciotomowej serii dokumentalno-wspomnieniowej Goli otok, określanej jako opus magnum autora, która ze względu na długi, prowadzony $\mathrm{w}$ ukryciu proces powstawania (pierwszy tom został opublikowany w 1990 roku, drugi i trzeci w 1995 roku, czwarty i piąty kolejno w latach 2011 i 2012), charakter narracji (podstawę stanowią wywiady z byłymi więźniami) i rolę, jaką odegrała w modelowaniu dyskusji na temat obozu, jest zestawiana z dziełem Aleksandra Sołżenicyna Archipelag GUŁag 1918-1956. Mihailović ponadto sam również wskazywał jako główną inspirację dzieło rosyjskiego pisarza (Taczyńska 183). Jako analogia do nazwy radzieckiego Gułagu w (post)jugosłowiańskiej historiografii zaczęła funkcjonować nawet metafora "Archipelag Goły” (Kosić 17). W świadomości społecznej odwoływanie się do sowieckiego terroru znalazło swoje uzasadnienie i wyraźnie naznaczyło perspektywę odczytywania świadectw byłych więźniów. Jednak gdy w 1998 roku podczas konferencji naukowej Konflikt jugosłowiańsko-sowiecki 1948, zorganizowanej przez Instytut Historii Współczesnej w Belgradzie, Mihailović wygłosił referat zatytułowany Goli otok - na tropie Gułagu i Holokaustu, wywołał wśród słuchaczy oburzenie i sprzeciw ze względu na porównanie obozu Goli otok do tragedii Shoah (Mihailović 336). Przykłady można by mnożyć, a każde

3 Kwestia poczucia winy u byłych więźniów nie została jak dotąd zbadana i opisana w dyskursie obozowym, jej przejawy można jednak odnaleźć w różnych świadectwach, na przykład w wywiadzie udzielonym Tihej K. Gudac w filmie Goli przez Verę Winter. 
kolejne ich przytoczenie wymagałoby wprowadzenia i zdefiniowania kontekstów nazistowskiego i sowieckiego $\mathrm{w}$ przestrzeni jugosłowiańskiej, co nie jest tematem tego tekstu. Ilustracja problematyki poprzez osobę, twórczość i działania Mihailovicia miała pokazać, że centralne, mocno osadzone $\mathrm{w}$ dyskusjach narodowych i globalnych totalitaryzmy (nazistowski i sowiecki) są stałym elementem debaty publicznej na temat konfliktów wewnętrznych w wielu krajach. Ich użycie poprzez porównanie często jest świadomym gestem mówiącego, którego odczytanie wymaga znajomości właściwych dla danego obszaru społeczno-politycznego i kulturowego kontekstu.

Wróćmy teraz do monografii Morawca i przyjrzyjmy się konstrukcji publikacji. Książka składa się z jedenastu tematycznie (sugestywnie zwerbalizowanych) rozdziałów, które poprzedza wstęp. Autor wyjaśnia w nim przede wszystkim powody zainteresowania tematem, założenia pracy i omawia okoliczności towarzyszące kształtowaniu się dyskursu polskiej literatury na temat ludobójczej przemocy. W trakcie lektury można odnieść wrażenie, że historia i narracje, które konstruuje Morawiec, znakomity badacz polskiej literatury wojennej i obozowej, rodziły się $\mathrm{w}$ trybie długodystansowym jako zapisywane od lat notatki, tworzone na marginesie dotychczasowych studiów, w formie komentarzy, zastrzeżeń, wątpliwości, których znaczenie pewnego dnia zostało poddane weryfikacji, a złożoność szczegółowym analizom. Peryferyjne uwagi w prezentowanej monografii z pozycji drugorzędnej wysuwają się na plan pierwszy. Na ten wertykalny układ z kolei nakładają się warstwy pamięci, ich wielopoziomowość, która podlega zmianom w czasie. Obrazowo i wyraziście przedstawiają te kwestie rozdziały pierwszy i drugi, poświęcone zagładzie Ormian - określanej czasem jako pierwsze ludobójstwo w XX wieku. Eksterminacja Ormian zarówno w polskiej historiografii, jak i w literaturze nie pojawiała się jako temat główny, lecz raczej w ograniczonym zakresie, okazjonalnie, może wręcz chaotycznie. Morawiec natomiast odnajduje te ślady obecności (przypadek Przedwiośnia Stefana Żeromskiego), porządkuje i przesuwa akcenty, przez co pomijane i uznawane za mniej ciekawe (też udane) fragmenty nabierają nowych treści.

W pewną paralelę mogłyby zostać ujęte rozdziały trzeci i dziesiąty. Oba opowiadają o traumach, które długo były (zagłada Romów) lub nadal są (zagłada osób upośledzonych i psychicznie chorych) niewypowiedziane i niesłyszalne. Dynamika kulturowej recepcji lub jej braku łączy się w dużej mierze z przeświadczeniem o nieobecności świadectw pozostawionych przez ofiary należące do grupy Romów oraz osób upośledzonych i psychicznie chorych. W tym miejscu trzeba zasygnalizować świadomie i konsekwentnie stosowany przez Morawca zabieg językowy - badacz celowo Romów nazywa Cyganami, a osoby niepełnosprawne intelektualnie upośledzonymi, zatem używa słów, które z dzisiejszej perspektywy ocenilibyśmy jako niepoprawne politycznie. $W$ intencji badacza takie działanie ma przede wszystkim podkreślić, iż w czasie drugiej wojny światowej nie istniały nienacechowane, nie- 
wartościujące określenia, więc ich stosowanie byłoby zafałszowaniem obrazu historycznego.

Niesłuszne przekonanie o nieistnieniu romskich świadectw o zagładzie z czasem uległo zmianie. Najpierw grupy aktywistów w latach siedemdziesiątych ubiegłego wieku poprzez swoje działania zaczęły głośno domagać się uznania dokonanego na ich narodzie ludobójstwa. W Polsce na tym polu nieoceniona okazała się praca Jerzego Ficowskiego, który, co warto podkreślić, już w latach czterdziestych zbierał relacje ocalonych. Morawiec w tym miejscu opisuje działania Głównej Komisji Badania Zbrodni Niemieckich w Polsce, której Ficowski przekazał materiały. Wówczas jednak Komisja nie była zainteresowana martyrologią ludności romskiej i właściwy zwrot przyszedł dopiero w latach dziewięćdziesiątych. Starania Ficowskiego wsparł Wacław Długoborski, który doprowadził do tego, by w 1991 roku Państwowe Muzeum Oświęcim-Brzezinka zorganizowało międzynarodową sesję naukową Sinti $i$ Romowie w KL Auschwitz $i$ ich los w latach 1933-1945. W tym samym roku zostało również utworzone Stowarzyszenie Romów w Polsce z siedzibą w Oświęcimiu. Morawiec przypomina również, że w 2011 roku Sejm Rzeczypospolitej Polskiej dzień 2 sierpnia ustanowił Dniem Pamięci o Zagładzie Romów i Sinti. W przypadku członków tej grupy marginalna refleksja o romskiej pamięci zagłady wynikała dodatkowo ze społecznej dyskryminacji Romów i specyfiki ich kodu kulturowego. Problematyka nieobecności czy niesłyszalności romskiego głosu stała się $\mathrm{w}$ ostatnich latach przedmiotem zainteresowania na gruncie polskiej nauki (opracowania Sławomira Kapralskiego, Lecha Mroza). Mimo wszystko jednak w przestrzeni publicznej, jak konstatuje Morawiec, choć „zbrodnia ta nie należy do kategorii «zapomnianych ludobójstw», trudno ją uznać za powszechnie i dobrze znaną" (Morawiec 2018a: 263).

O grupie osób psychicznie chorych i upośledzonych jako ofiarach zbrodni popełnionych przez nazistów mówiło się w historiografii rzadko, ich głos pozostaje wyjątkowo słaby. W tym miejscu dodać należy, co podkreśla Morawiec: „Tę listę ofiar, a właściwie ich kategorii (nie zawsze rozłącznych), można by uzupełniać" (Morawiec 2018a: 86). Coraz częściej na przykład rzeczowo dyskutuje się na temat prześladowań w Trzeciej Rzeszy homoseksualistów czy Świadków Jehowy. Osoby dotknięte chorobą psychiczną można by, posługując się śródtytułem z rozdziału trzeciego, określić jako „ofiary bez głosu”. W tym przypadku pustka wywołana nieobecnością świadectw jest szczególnie dotkliwa, podobnie jak brak działaczy, którzy mogliby upomnieć się o pamięć grupy. Ponownie jednak, jak pokazuje Morawiec, choć ich liczba jest znikoma, nie oznacza to, że nie ma ich wcale (wspomnienie Hansa Ralfsa), nawet jeśli ich obecność ma charakter potencjalny (nieistniejące świadectwo Jerzego Jankowskiego). Gdyby jednak skierować uwagę, jak czyni to autor, w stronę zapisów świadków, sytuacja rysuje się nieco odmiennie. Wydaje się, iż działania polskiego badacza można rozpatrywać jako rodzaj medium, Morawiec jako dociekliwy poszukiwacz głosów staje się empatycznym wyrazicielem 
doświadczenia ofiar lub też w możliwie najlepszy sposób stara się do nich przybliżyć. Opowieść literaturoznawcy wpisuje się tym samym w nurt przeciw-historii Michela Foucaulta lub koncepcję historii ratowniczej Ewy Domańskiej, w której uwzględnia się historię zwyciężonych i zapomnianych oraz tworzy „zwróconą ku przyszłości historię krytycznej nadziei i obietnicy", refleksję afirmatywną, przywracającą zdarzenia z przeszłości i budującą (czasem przy użyciu wyobraźni) wiedzę historyczną (Domańska 16-17).

Szczególne miejsce w rozważaniach polskiego literaturoznawcy, jako centralny w polskiej rzeczywistości kulturowej, zajmuje dyskurs Holokaustowy, nierzadko sprawiający wrażenie nienaruszalnego, stałego, niezmiennego, a z pewnością mocno osadzonego w historii literatury. Raz wyartykułowane sądy, arbitralne oceny oraz wypracowane strategie opisu i interpretacje kolejni czytelnicy, nauczyciele, studenci i uczniowie po prostu powtarzają. W odczytaniu Morawca ten niejako naturalny porządek zostaje naruszony, zniuansowany i odświeżony. We wstępie badacz zwraca uwagę, że studia poświęcone literaturze Holokaustu traktować należy jako potrzebę „wzbogacenia stanu badań, a w niektórych przypadkach - korektę istniejących (niekiedy pokutujących) ustaleń" (Morawiec 2018a: 27). Rozważania związane z Holokaustem obejmują rozdziały od czwartego do dziewiątego. Czytelnik może odnaleźć w nich kolejno: spostrzeżenia na temat legendy literackiej Władysława Szlengla, kronikarza i najwybitniejszego poety warszawskiego getta tworzącego $\mathrm{w}$ języku polskim; studium przyczynkowe na temat recepcji wiersza Juliana Tuwima Lokomotywa, której wyrazem są „holokaustowe” parafrazy autorstwa dzieci, powstałe w gettach i obozach koncentracyjnych; analizę wspomnień Leona Weliczkera, więźnia „obozu janowskiego”, miejsca właściwie nieznanego w polskiej przestrzeni, usytuowanego przy ulicy Janowskiej we Lwowie, charakteryzującego się szczególnym okrucieństwem; szczegółowe dociekania dotyczące procesu powstawania Medalionów Zofii Nałkowskiej oraz wykorzystania przez autorkę dokumentów w literackim przetworzeniu; ponadto Morawiec bada udział Nałkowskiej w tworzeniu "czarnej legendy" profesora Rudolfa Spannera i rozważa jednocześnie konsekwencje płynące z bezrefleksyjnego uznawania literatury za pierwszorzędne źródło historyczne, co niewątpliwie ma miejsce w przypadku Medalionów funkcjonujących jednocześnie jako tekst literacki i świadectwo; uwagi na temat źródeł inspiracji, w ocenie Morawca, mających fundamentalne znaczenie dla kształtowania się wyobraźni pisarskiej Tadeusza Różewicza, której wyraz odnajdujemy w utworach Wycieczka do muzeum, Rzeź chłopców i Warkoczyk.

Książkę zamyka rozdział poświęcony literackim i pozaliterackim tekstom na temat dokonanej przez Serbów w 1995 roku masakry w Srebrenicy, uważanej za ostatni w XX wieku przejaw ludobójstwa w Europie. Różnorodność i wielość tych tekstów powoduje, że ich wymienianie byłoby $\mathrm{w}$ tym miejscu $\mathrm{w}$ istocie niemożliwe (i raczej bezcelowe). Morawiec w omawianej części, istniejącej na zasadzie epilogu w monografii, chronologicznie i konfrontatywnie omawia sposoby literackiej reprezentacji 
zbrodni, szuka odpowiedzi na pytanie o nadrzędną kategorię i motywy dominujące $\mathrm{w}$ literaturze polskiej oraz porządkuje formy przedstawiania wojny domowej w Jugosławii. Badacz bliżej przygląda się także (de)formowaniu (propagandowego) obrazu masakry na gruncie literatury oraz ogromnej roli "nowych mediów” w jego tworzeniu. A zatem z jednej strony omawia problemowe i estetyczne wykładniki tej literatury, a z drugiej pochyla się nad ich poznawczą i społeczną funkcją.

W podsumowaniu dodać należy, że celem Morawca nie było - co wydaje się oczywiste - całościowe i panoramiczne usystematyzowanie literatury polskiej na temat ludobójstwa. Gigantyczny korpus tekstów wchodzących w obszar analizowanej przez autora tematyki nie pozwala na jej ujęcie w ramach jednej publikacji. Polski literaturoznawca traktuje swoją monografię, bez wątpienia intelektualnie wartościową, jako katalog wstępny, który na dalszych etapach będzie uzupełniany i wzbogacany:

Chciałbym, aby książka Literatura polska wobec ludobójstwa stanowiła impuls dla badaczy do stworzenia w przyszłości możliwie pełnego obrazu polskiej, a w dalszej perspektywie również obcojęzycznej, literatury ludobójstwa, na podobieństwo istniejących już monografii i encyklopedii literatury Holokaustu (Morawiec 2018a: 28).

Dziś, w czasie gdy Europa coraz mocniej zwraca się w stronę dziewiętnastowiecznego myślenia o wielkości narodów, Morawiec przekierowuje spojrzenie czytelnika w stronę literatury, która choć daleka jest od doskonałości, podejmuje próby "zbliżenia się do" konsekwencji takiej wizji, której rezultatem stać się mogą wojny i ludobójstwo.

\section{BIBLIOGRAFIA}

Domańska, Ewa. „Historia ratownicza”. Teksty Drugie 5 (2014). S. 12-26.

Jezernik, Božidar. Naga Wyspa. Gułag Tity. Przeł. Joanna Pomorska, Joanna Sławińska. Wołowiec: Czarne, 2013 .

Kosić, Ivan. Goli otok. Najueći Titov konclogor. Zagreb: Udruga Goi otok „Ante Zemljar”, 2009.

Mihailović, Dragoslav. Goli otok. T. 5. Beograd: Službeni glasnik, 2012.

Morawiec, Arkadiusz. Literatura polska wobec ludobójstwa. Rekonesans. Łódź: Wydawnictwo Uniwersytetu Łódzkiego, 2018a.

Morawiec, Arkadiusz. „Wstęp”. Acta Universitatis Lodziensis. Folia Litteraria Polonica: Lager, tagier, obóz zapis. Lektury 1 (2018b). S. 5-6.

Simić Dragoslav, Trifunović Boško, red. Ženski logor na Golom otoku. Ispovesti kažnjenica i islednice. Beograd: ABC Product, 1990.

Taczyńska, Katarzyna. Dowcip trwający dwa i pót roku. Obraz Nagiej Wyspy w serbskim dyskursie literackim i historycznym końca XX i początku XXI wieku. Warszawa, Bellerive-sur-Allier: DiG, 2016. 